ISSN. 2775-4324 (Online)

Journal of Physical Activity and Sports

Volume 2, Nomor 3, Desember 2021, 339-346

Journal of Physical Activity and Sports

\title{
Pengaruh Tutor Sebaya Dan Role Playing Terhadap Keterampilan Sosial dan Passing Sepakbola
}

\author{
Hasan Fahmi ${ }^{1}$, Setiyawan ${ }^{2}$, Fajar Ari Widiyatmoko ${ }^{3}$ \\ ${ }^{1}$ Universitas PGRI Semarang. Jl. Gajah Raya No.30 B, Sambirejo, Kec. Gayamsari, Kota Semarang, Jawa \\ Tengah 50166 \\ ${ }^{2}$ Universitas PGRI Semarang. Jl. Gajah Raya No.30 B, Sambirejo, Kec. Gayamsari, Kota Semarang, Jawa \\ Tengah 50166 \\ ${ }^{3}$ Universitas PGRI Semarang. Jl. Gajah Raya No.30 B, Sambirejo, Kec. Gayamsari, Kota Semarang, Jawa \\ Tengah 50166 \\ fahmihasan431@gmail.com ${ }^{1}$, second.setiyawan@gmail.com ${ }^{2}$ fajarariwidyiatmoko@upgris.ac.id ${ }^{3}$
}

\begin{abstract}
The purpose of this study was to determine the differences in learning outcomes of peer tutor learning methods and learning methods of role playing soccer passing techniques in Class XI students of SMA Futuhiyyah Mranggen. The research method is a quantitative approach, in the form of a True Experimental Design with a type of Nonequivalen Conrol Group Design. The study population was students of class XI IPS 1 and XI IPS 2 SMA Futuhiyyah Mranggen. The data in the study were obtained through learning outcomes tests and social skills tests. The discussion of the research results was carried out based on the theory of teacher professionalism and learning outcomes. Based on the results of the analysis after receiving treatment, it shows that: 1). There is a significant effect of peer tutoring learning methods on social skills and soccer passing learning outcomes in class XI SMA Futuhiyyah Mranggen 2). There is a significant effect of the role playing learning method on social skills and learning outcomes of soccer passing in class XI SMA Futuhiyyah Mranggen. 3). Role playing method is more effective in improving social skills and learning outcomes of soccer passing in class XI SMA Futuhiyyah Mranggen.
\end{abstract}

Keywords: Peer Tutor, Role Playing, Social Skills, Passing Football

\begin{abstract}
Abstrak
Tujuan penelitian ini untuk mengetahui perbedaan hasil belajar metode pembelajaran tutor sebaya dan metode pembelajaran role playing teknik passing sepakbola pada Siswa Kelas XI SMA Futuhiyyah Mranggen. Metode penelitian pendekatan kuantitatif, dalam bentuk True Eksperimental Design dengan jenis Nonequivalen Conrol Group Design.Populasi penelitian adalah siswa kelas XI IPS 1 dan XI IPS 2 SMA Futuhiyyah Mranggen. Data dalam penelitian diperoleh melalui tes hasil belajar dan tes keterampilan sosial. Pembahasan hasil penelitian dilakukan dengan berpedoman pada teori profesionalisme guru dan hasil beajar. Berdasarkan hasil analisis setelah medapatkan perlakuan menunjukan bahwa : 1). Pengaruh yang signifikan metode pembelajaran tutor sebaya terhadap keterampilan sosial dan hasil belajar passing sepakbola kelas XI SMA Futuhiyyah Mranggen 2). Ada pengaruh yang signifikan metode pembelajaran role playing terhadap keterampilan sosial dan hasil belajar passing sepakbola kelas XI SMA Futuhiyyah Mranggen. 3). Metode role playing lebih efektif dalam meningkatkan keterampilan sosial dan hasil belajar passing sepakbola pada siswa kelas XI SMA Futuhiyyah Mranggen.
\end{abstract}

Kata kunci: Tutor Sebaya, Role Playing, Ketarampilan sosial, Passing Sepakbola 
Pengaruh Tutor Sebaya dan Role Playing Terhadap Keterampilan Sosial \& Passing Sepakbola ... Hasan Fahmi 1, Setiyawan 2, Fajar Ari Widiyatmoko 3

340

\section{PENDAHULUAN}

Pendidikan pada hakekatnya merupakan proses pembangunan bangsa secara keseluruhan dan bertujuan dalam mengembangkan aspek-aspek kehidupan terutama dalam masa reformasi yang serba transparan seperti sekarang ini (Mikkey \& Suganda, 2013). Pendidikan adalah suatu bentuk perwujudan kebudayaan manusia yang selalu ingin belajar dan surat dengan ingin tahuan akan ilmu pengetahuan (Ramadan, 2017). Pendidikan jasmani di sekolah memiliki peranan yang sangat penting, sehingga siswa dapat terlibat dalam proses pembelajaran yang diarahkan guna pembinaan pertumbuhan fisik dan perkembangan psikis, serta membentuk pola hidup yang sehat dan bugar, sehingga tujuan pembelajaran yang akan dicapai harus didukung oleh antusias dan keaktifan dalam mengikuti pembelajaran (Hakim, Amiq, \& Yudasmara, 2018). Pendidikan jasmani pada dasarnya merupakan bagian integral dari sistem pendidikan secara keseluruhan, bertujuan untuk mengembangkan aspek kesehatan, kebugaran jasmani, keterampilan berfikir kritis, penalaran, keterampilan sosial melalui aktivitas jasmani dan olahraga.

Olahraga sendiri adalah salah satu bagian kegiatan yang sangat penting bagi kehidupan manusia, karena dengan berolahraga memerlukan aktivitas fisik.Menurut (Febrianto, A \& Kartiko, 2014) olahraga merupakan suatu kegiatan atau permainan yang begitu menyenangkan sehingga banyak siswa yang tertarik untuk mengembangkan bakat dan kemampuan melalui jenis kegiatan atau permainan yang disukainya. Hal tersebut membuat para guru harus dapat memutar otak untuk dapat menerapkan pembelajaran yang efektif dan digemari oleh siswa. Dalam pembelajaran pendidikan jasmani, berhasil tidaknya pembelajaran ditentukan oleh peran guru pendidikan jasmani. Oleh karena itu guru harus sungguh-sungguh dalam menanganinya, khususnya guru pendidikan jasmani sebagai pendidik yang berarti meneruskan dan mengembangkan keterampilan gerak pada peserta didik.

Tutor adalah siswa yang sebaya yang ditunjuk atau ditugaskan membantu temannya yang mengalami kesulitan belajar, karena hubungan antar teman umumnya lebih dekat dibandingkan dengan guru (Fuad \& Sudarso, 2014). Tutor adalah orang yang memberi pelajaran (membimbing) kepada seseorang atau sejumlah kecil siswa (Falah, 2014). Jadi, seseorang yang memberikan bimbingan dalam kegiatan tutorial sebaya disebut dengan tutor.Sebagaimana di dalam undangundang RI. No. 20 tahun 2003 tentang Sistem Pendidikan Nasional dijelaskan bahwa Pendidik adalah tenaga kependidikan yang berkualifikasi sebagai guru, dosen, konselor, pamong belajar, widyaiswara, tutor, instruktur, fasilitator dan sebutan lain yang sesuai dengan kekhususannya, serta berpartisipasi dalam menyelenggarakan pendidikan.

Metode pembelajaran role playing adalah suatau cara penguasaan bahan pembelajaran melalui pengembangan imajinasi dan penghayatan siswa (Mustofa \& Sudarso, 2017). Belajar role playing sebagai alternatif metode yang dapat mengaktifkan siswa dan merangsang siswa agar berani mengemukakan pendapat, menganalaisis, memecahkan masalah dan merangsang aktivitas dan 
Pengaruh Tutor Sebaya dan Role Playing Terhadap Keterampilan Sosial \& Passing Sepakbola ... Hasan Fahmi 1, Setiyawan 2, Fajar Ari Widiyatmoko 3

341

kreativitas belajar siswa yaitu bermain peran (Saputra, 2015). Dengan demikian, dalam pembelajaran role playing siswa akan lebih aktif selama dan setelah meperagakan drama atau mendengarkan suatu drama, dibandingkan jika siswa belajar secara individual.

Berdasarkan hasil observasi dan penemuan masalah di SMA Futuhiyyah Mranggen nilai siswa masih kurang dari KKM, yang mencapai KKM hanya 30\% dari banyaknya 32 siswa, sedangkan kiteria ketuntasan minimal (KKM) pada tempat penelitian sebesar 70. Selain itu dalam proses pembelajaran yang sedang dilakukan seorang guru secara konvensional tanpa melakukan variasi metode pembelajaran yang yang disesuaikan dengan materi yang diajarkan. Pembelajaran konvensional merupakan metode pembelajaran yang secara rutin dilakukan dengan cara dan ururtan yang relatif sama.

Berdasarkan latar belakang masalah di atas peneliti memilih metode pembelajaran tutor sebaya dan metode pembelajaran role playing diharapkan siswa semakin semangat dan antusias dikarenakan ada suatu yang berbeda dan ingin mengetahui pengaruh pembelajaran tutor sebaya dan role playing, karena belum diketahui pengarunya. Dari itu peneliti ingin melakukan penelitian dengan berjudul "pengaruh tutor sebaya dan role playing terhadap keterampilan soasial dan passing sepakbola".

\section{METODE}

Metode penelitian yang digunakan pada penelitian ini adalah True Eksperimental Design. Menurut Sugiono dalam (Farid 2018: 44) desain ini mempunyai kelompok kontrol, tetapi tidak dapat berfungsi sepenuhnya untuk mengontrol vaiabel-variabel luar yang mempengaruhi pelaksanaan eksperimen. variabel bebas yang dimanipulasikan dalam penelitian ini adalah tutor sebaya dan role playing, sedangkan untuk variable terikatnya adalah keterampilan sosial dan passing sepakbola.

Dalam pengambilan sampel terdapat berbagai teknik. Penelitian ini menggunakan teknik Probability Sampling. Menurut Sugiono, (2014:91) Probability Sampling adalah teknik sampling yang memberi peluang sama kepada anggota populasi untuk dipilih menjadi anggota sampel. Sedangakan penelitian ini menggunakan desain Nonequivalen Control Group Design, desain ini hampir sama dengan pretest-postest control group design, hanya saja desain ini kelompok eksperimen dan kelompok kontrol tidak dipilih secara random. 
Pengaruh Tutor Sebaya dan Role Playing Terhadap Keterampilan Sosial \& Passing Sepakbola... Hasan Fahmi 1, Setiyawan 2, Fajar Ari Widiyatmoko 3

342

$$
\begin{aligned}
\mathrm{K}_{1}: \text { pretest } & \longrightarrow \mathrm{X} 1 \longrightarrow \text { postest } \\
\mathrm{K}_{2}: \text { pretest } & \longrightarrow \mathrm{X} 2 \longrightarrow \text { postest }
\end{aligned}
$$

Gambar 1 Desain penelitian Nonequivalen Control Group Design

Keterangan:

K1: Kelas dengan penerapan tutor sebaya (kelas eksperimen)

$\mathrm{K} 2$ : Kelas dengan penerapan role playing (kelas eksperimen)

X1: Penerapan tutor sebaya

$\mathrm{X} 2$ : Penerapan role playing

Karena populasi yang dilakukan dalam penelitian ini jumlahnya lebih dari satu kelas yaitu kelas XI MIPA terdiri 5 kelas dan kelas XI IPS terdiri dari 3 kelas, maka pengambilan teknik secara random/acak dapat dilakukan dengan undian. Maka pengambilan sampel di dapatkan dalam penelitian ini adalah siswa kelas X1 IPS 1 dan X1 IPS 2 SMA Futuhiyyah Mranggen. Dan kelas yang mendapatkan metode tutor sebaya adalah siswa kelas XI IPS 1 dan kelas yang mendapatkan metode role playing adalah kelas XI IPS 2.

Teknik dan instrument pengumpulan data yang digunakan dalam penelitian ini yaitu tes hasil belajar dan tes keterampilan sosial. Tes hasil belajar yang digunakan berupa eksperimen pengumpulan data berupa tes keterampilan teknik dasar passing sepakbola. Adapun tahap-tahap dalam pengumpulan data meliputi tahap persiapan, tahap pelaksanaan, dan pelaporan hasil pengumpulan data. Sedangkan tes keterampilan sosial yaitu menggunakan tes angket keterampialn sosial yang dilakukan oleh (Ridiansyah, P. N, 2016) item pertanyaan yang terdapat dalam angket kuesioner meliputi: 1). kerjasama yaitu perilaku yang digunakan seperti membantu orang lain, berbagi alat, mematuhi aturan dan instruksi , 2). Ketegasan yaitu meminya informasi pada orang lain, memperkenalkan diri sendiri, merespon perilaku orang lain (tekanan teman sebaya atau peghinaan) 3). Empati yaitu perilaku yang menunjukan kepeduliaan dan penghormatan perasaan dan sudut pandang orang lain, memahami perasaan teman, meminta bantuan, 4). kontrol diri yaitu perilaku yang muncul dalam situasi konflik, seperti merespon dengan tepat pada gangguan/godaan, dan situasi non konflik, tidak mudah marah dan menahan diri. Angket kuesioner keterampilan sosial untuk mengukur motivasi belajar siswa. 
Pengaruh Tutor Sebaya dan Role Playing Terhadap Keterampilan Sosial \& Passing Sepakbola ... Hasan Fahmi 1, Setiyawan 2, Fajar Ari Widiyatmoko 3

343

Pada penelitian ini teknik analisis data yang digunakan adalah teknik analisis statistik menggunakan uji-t dengan bantuan analisis statistic data SPSS. Uji normalitas untuk mengetahui normal tidaknya distribusi/sebaran data yang diperoleh uji normalitas ini menggunakan teknik Kolmogorov-Smirnov. Untuk mengetahui normal tidaknya data adalah jika p > 0,05 maka sebaran data dianggap normal, sebaliknya jika $\mathrm{p}<0,05$ sebaran dikatakan tidak normal. Arrahman dalam (Farid, 2018: 51).untuk mengetahui apakah kelompok data berasal dari populasi yang memiliki varians yang sama atau tidak. kriteria pengambilan keputusan adalah apabila nilai sig $>0,05$ atau $\mathrm{F}$ hitung $<$ F table, berarti sampel tersebut homogen. Jika $<0,05$ maka data dianggap tidak berasal dari varianyang sama dan data ditolak. Arrahman dalam (Farid, 2018: 51).

Setelah data memenuhi syarat untuk dianalisis maka langkah selanjutnya uji hipotesis ini menggunakan uji-t dan ANOVA (Analysis of Variance) Untuk mengetahui signifikasi atau ada tidaknya perbedaan hasil belajar pasing sepakbola pada kelas tutor sebaya dan kelas role playing. Maka hasil thitung dikonsultasikan dengan ttabel pada taraf signifikasi 5\%. Apabila harga thitung lebih besar dari ttabel maka terdapat perbedaan yang signifikan hasil belajar pasing sepakbola pada kelas tutor sebaya dan kelas role playing, dengan demikian hipotesis nol (Ho) ditolak dengan hipotesis kerja diterima (Ha). Arrahman dalam (Farid, 2018: 52).

\section{HASIL DAN PEMBAHASAN}

Berdasarkan tabel di bawah dapat dikemukakan sebagai berikut: Berdasarkan Tabel 1, diperoleh nilai $\mid$ Thitung $|=|-3,732 \mid>$ Ttabel $(2,0030)$ dan nilai Sig. $(0,000)<\alpha(0.05)$ maka H0 ditolak dan Ha diterima, yang berarti ada perbedaan pengaruh pemberian metode pembelajaran tutor sebaya dengan role playing terhadap hasil belajar passing sepakbola pada siswa kelas XI SMA Futuhiyyah Mranggen. Dimana rata-rata hasil belajar passing sepakbola dengan metode tutor sebaya sebesar 82,879 sedangkan rata-rata hasil belajar passing sepakbola dengan metode role playing sebesar 85,103 .

Berdasarkan Tabel 2, diperoleh nilai $\mid$ Thitung $|=|-4,360 \mid>$ Ttabel $(2,0030)$ dan nilai Sig. $(0,000)<$ $\alpha(0.05)$ maka $\mathrm{H} 0$ ditolak dan Ha diterima, yang berarti ada perbedaan pengaruh pemberian metode pembelajaran tutor sebaya dengan role playing terhadap keterampilan sosial pada pembelajaran teknik passing sepakbola pada siswa kelas XI SMA Futuhiyyah Mranggen. Dimana rata-rata skor keterampilan sosial dengan metode tutor sebaya sebesar 133,58 dan rata-rataskor keterampilan sosial dengan metode role playing sebesar 141,41.

Berdasarkan Tabel 3, diperoleh hasil peningkatan keterampilan sosial dan hasil belajar passing sepakbola siswa kelas XI SMA Futuhiyyah Mranggen dengan metode tutor sebaya terjadi peningkatan sebesar $10,42 \%$ sedangkan dengan metode role playing terjadi peningkatan sebesar 
Pengaruh Tutor Sebaya dan Role Playing Terhadap Keterampilan Sosial \& Passing Sepakbola ... Hasan Fahmi 1, Setiyawan 2, Fajar Ari Widiyatmoko 3

344

10,78\%. Hasil belajar passing sepakbola siswa kelas XI SMAFutuhiyyah Mranggen dengan metode tutor sebaya terjadi peningkatan sebesar $34,14 \%$ sedangkan dengan metode role playing terjadi peningkatan sebesar 38,66\%. Dari hasil tersebut dapat diperoleh kesimpulan bahwa metode role playing lebih efektif untuk meningkatkan keterampilan sosial dan hasil belajar passing sepakbola siswa kelas XI SMA Futuhiyyah Mranggen.

Tabel 1 Hasil Belajar Passing Sepakbola Dengan Metode Tutor Sebaya dan Role Playing

\begin{tabular}{ccccc}
\hline Metode & Rata-Rata & Thitung & Ttabel $(5 \%, \mathrm{df}=60)$ & Sig.(2-tailed) \\
\hline Tutor Sebaya & 82,879 & & \multirow{2}{*}{2,00030} & 0,000 \\
Role Playing & 85,103 & $-3,732$ & & \\
\hline
\end{tabular}

Tabel 2 Keterampilan Sosial Dengan Metode Tutor Sebaya dan Role Playing

\begin{tabular}{lllll}
\hline Metode & Rata-Rata & Thitung & Ttabel $(5 \%, \mathrm{df}=60)$ & Sig.(2-tailed) \\
\hline Tutor Sebaya & 133,58 & & & \\
Role Playing & 141,41 & $-4,360$ & 2,00030 & 0,000 \\
\hline
\end{tabular}

Tabel 3 Peningkatan Keterampilan Sosial dan Hasil Belajar Passing Sepakbola Siswa Kelas XI SMA Futuhiyyah Mranggen

\begin{tabular}{llllll}
\hline Variabel & Metode & Hasil & Rata-Rata & Selisih & Peningkatan \\
\hline \multirow{3}{*}{ Keterampilan } & Tutor Sebaya (XI & Pretest & 120,970 & \multirow{2}{*}{ Pr,61 } & \multirow{2}{*}{$10,42 \%$} \\
Sosial & IPS 1) & Posttest & 133,576 & & \\
& Role Playing (XI & Pretest & 127,655 & & \\
& IPS 2) & Posttest & 141,414 & 13,76 & $10,78 \%$ \\
& Tutor Sebaya (XI & Pretest & 61,785 & & \\
\multirow{3}{*}{ Hasil Belajar } & IPS 1) & Posttest & 82,879 & 21,09 & \multirow{2}{*}{$34,14 \%$} \\
& Role Playing (XI & Pretest & 61,376 & 23,73 & \multirow{2}{*}{$38,66 \%$} \\
& IPS 2) & & & & \\
\hline
\end{tabular}

Berdasarkan uji hipotesis terdapat perbedaan pengaruh hasil belajar metode tutor sebaya dan metode role playing. Berdasarkan nilai skor akhir hasil belajar passing sepakbola, kelompok perlakuan dengan metode role playing mendapat hasil lebih tinggi dari pada kelompok perlakuan metode tutor sebaya. 
Pengaruh Tutor Sebaya dan Role Playing Terhadap Keterampilan Sosial \& Passing Sepakbola ... Hasan Fahmi 1, Setiyawan 2, Fajar Ari Widiyatmoko 3

Hasil belajar passing sepakbola dengan metode role playing lebih tinggi dikarenakan dengan perlakuan metode role playing siswa dapat mengetahui dan mengamati metode bermain passing sepakbola, dikarenakan jenis metode yang diberikan berupa bermain yang dapat dipertandingkan dengan satu kelompok yang sama sehingga proses pembelajaran sangat jelas dan siswa paham akan materi yang telah disampaikan. Dan perilaku yang ditunjukan seperti membantu orang lain dengan mematuhi instruksi yang ada menjadikan adanya perilaku sosial didalamnya. Sedangkan dalam perlakuan metode tutor sebaya penyampaian materi passing sepakbola yang kurang efektif dan cukup singkat, sehingga siswa hanya mengamati contoh yang diberikan lalu melakukan berbagai gerakan passing sepakbola dengan kurang maksimal dalam perlakuan, dan perilaku yang menunjukan kepeduliaan dan menghormati perasaan sudut pandang orang lain terhadap sikap sosialnya kurang.

Penelitian ini didukung oleh penelitian terdahulu yang dilakukan oleh Muhammad Fuad dan Sudarso (2014) yang berjudul "Pengaruh Metode Pembelajaran Tutor Sebaya Terhadap Hasil Belajar Dribble Sepakbola Pada Siswa Kelas VII SMP Negeri 1 Ganteng Banyuwangi. "Menyimpulkan bahwa terdapat adanya pengaruh metode tutor sebaya terhadap hasi belajar dribble sepakbola, sehingga metode tutor sebaya dikatakana lebih dominan bagi keterampilan driblle sepakbola terhadap hasil belajar pada siswa kels VII SMP Negeri 1 Ganteng Banyuwangi.

Sedangkan penelitian yang dilakukan oleh Dedi Rizkia Saputra (2015) mengenai "penerapan metode role playing untuk meningkatkan hasil belajar IPS pada siswa kelas V SD N 2 Kecemen Manisrenggo Klaten". Menyimpulkan bahwa adanya peningkatan metode role playing terhadap hasil belajar IPS, sehingga metode role playing dikatakan lebih dominan bagi pembelajaran IPS pada siswa kelas V SD N 2 Kecemen Manisrenggo Klaten.

\section{KESIMPULAN}

Berdasarkan hasil penelitian dan analisis data yang telah dilakukan oleh penulis, dapat diperoleh kesimpulan sebagai berikut: 1 . Ada pengaruh yang signifikan metode pembelajaran tutor sebaya terhadap keterampilan sosial dan hasil belajar passing sepakbola kelas XI SMA Futuhiyyah Mranggen. 2. Ada pengaruh yang signifikan metode pembelajaran role playing terhadap keterampilan sosial dan hasil belajar passing sepakbola kelas XI SMA Futuhiyyah Mranggen. 3. Metode role playing lebih efektif dalam meningkatkan keterampilan sosial dan hasil belajar passing sepakbola pada siswa kelas XI SMA Futuhiyyah Mranggen.

Maka dikemukakan saran-saran sebagai berikut: 1). Bagi guru diharapkan perlakuan metode pembelajaran tutor sebaya dan metode pembelajaran role playing dapat diaplikasikan pada pembelajaran gerak lain, 2). Bagi siswa diharapkan pembelajaran dengan menggunakan tutor sebaya 
Pengaruh Tutor Sebaya dan Role Playing Terhadap Keterampilan Sosial \& Passing Sepakbola ... Hasan Fahmi 1, Setiyawan 2, Fajar Ari Widiyatmoko 3

346

dan role playing dalam menyampaikan materi sepakbola dapat dijakan sebagai referensi serta variasi dalam menyampaikan materi khususnya pada pembelajaran keterampilan dasar sepakbola sehingga pembelajaran dapat tersampaikan dengan cara yang menarik dan lebih efisien, 3). Diharapkan bagi peneliti selanjutnya dapat mengembangkan penelitian serupa dengan variabel dan subjek yang berbeda khususnya dalam bidang olahraga yang akan diteliti dan dapat menjadikan skripsi ini sebagai acuan dan bahan referensi. Tambah demi mencapai kemampuan fisik dan mental yang maksimal.

\section{DAFTAR PUSTAKA}

Ariyanto, Farid. Bagus. (2018). Pengaruh metode hypnoteaching dan fun teaching terhadap minat belajar pjok pada siswa kelas VIII SMP Negeri 3 Mranggen. Semarang: Universitas PGRI Semarang.

Falah, I. F. (2014). Metode Pembelajaran Tutorial Sebaya: Telaah Teoritik. 12(2), 175-186.

Febrianto, A., \& Kartiko, D. C. (2014). Pengaruh Metode Pembelajaran Tutor Sebaya Terhadap Hasil Belajar Dribble Bola Basket (Studi Pada Siswa Kelas VII SMP Negeri 1 Prambon Sidoarjo). Jurnal-Pendidikan-Jasmani. 2(3) 783-786.

Fuad, M., \& Sudarso. (2014). Pengaruh Metode Pembelajaran Tutor Sebaya Terhadap Hasil Belajar Dribble Sepakbola (Studi Pada Siswa Kelas VIII SMP Negeri 1 Genteng Banyuwangi). Jurnal Pendidikan Olahraga Dan Kesehatan, 02(2), 388-392.

Hakim, L., Amiq, F., \& Yudasmara, D. S. (2018). Upaya Meningkatkan Keaktifan Siswa Dalam Pembelajaran Pendidikan Jasmani Menggunakan Metode Bermain Untuk Siswa Kelas V Sdn 2 Pagelaran Kabupaten Malang. Journal of Teaching Physical Education in Elementary School $1(5), 65-77$.

Mikkey, A., \& Suganda, S. (2013). Pengembangan Model Pembelajaran Bolavoli Pada Siswa Sekolah Dasar Kelas Atas Developing Volleyball Learning Models for Students of Upper Class of Elementary Schools. 1(2), 156-165.

Mustofa, M. A., \& Sudarso. (2017). Pengaruh Metode Pembelajaran Role Playing Terhadap Hasil Belajar Shooting Bola Basket. 05, 456-461.

ramadan, G. (2017). Pengaruh metode Pembelajaran Dan Motivasi Belajar Terhadap Hasil Belajar Passing Sepakbola.Jurnal Olahraga 2(1).

Ridiansyah, P. N. (2016). Pengaruh model pembelajaran teaching games for understanding terhadap keterampilan sosial dan keterampilan bermain bola basket. Bandung: Universitas Pendidikan Indonesia

Saputra, D. R. (2015). Penerapan Metode Role Playing Untuk Meningkatkan Hasil Belajar IPS Pada Siswa Kelas V SD Negeri 2 Kecemen, Manisrenggo, Klaten. (April), 1-10. 